\title{
TRINITY WESTERN UNIVERSITY LAW: THE BOUNDARY AND ETHOS OF THE LEGAL COMMUNITY
}

\author{
BLAIR A. MAJOR*
}

The article examines the conflict between the legal community and Trinity Western University (TWU) over TWU's proposed law school. The first half of the article is concerned with how this conflict shapes the boundary of the legal community. The second half shows how understanding the ethos of the legal community in terms of virtue, rather than abstract values such as equality, permits at least having regard for the religious ideas of TWU when framing the nature of the legal profession. TWU, the article suggests, challenges traditional views of legal education and the legal profession, and requires reconsideration of how communities define themselves.

\section{TABLE OF CONTENTS}

I. INTRODUCTION . . . . . . . . . . . . . . . . . . . . . . . . . . 167

II. Boundaries as SyMbOLIC MEANing $\ldots \ldots \ldots \ldots \ldots \ldots \ldots \ldots$

A. Discrimination, COERCiON, AND THE NATURE OF COMMUNITY . . . . . . . . . . . . 171

B. CONSTRUCTING COMMUNITY:

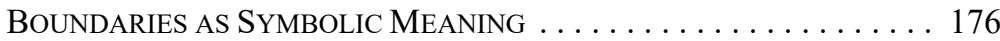

C. The Foundations OF COMMUNiTy:

BOUNDARY CROSSING AS "SUTURE" . . . . . . . . . . . . 179

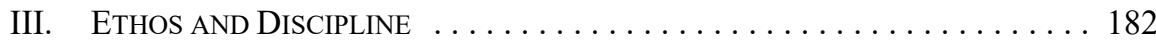

A. "The ETHOS OF THE Legal Profession":

VALUE OR ViRTUE? . . . . . . . . . . . . . . . . . . . 184

B. The Discipline of LaW School: The Divided Self . . . . . . . . . 189

C. The Challenge of TWU . . . . . . . . . . . . . . . . . . . . 193

IV. CONCLUSiOn: StRuCTURING THE CONFLiCT

IN TERMS OF COMMUNITY . . . . . . . . . . . . . . . . . . . . . . . 196

\section{INTRODUCTION}

[T]he attempt to fix the boundaries between church and state and the project of liberal theory (of finding an archimedean point to the side of, above, or below sectarian interest) are one and the same. They stand or fall together, and what would threaten their fall ... is a religion that does not respect the line between public and private, but would plant its flag everywhere. An uncompromising religion is a threat to liberalism because were it to be given full scope, there would be no designated, safe space in which toleration was the rule. ${ }^{1}$

The boundaries so central to ... law are the boundaries that feel desperately necessary to ... keep the threatening others at bay - the impossibility of that task only fueling the desperation. When I say the task is impossible, I do not mean to imply that the boundaries do nothing.

Candidate, Doctor of Civil Law, Faculty of Law, McGill University and SSHRC Joseph-Armand Bombardier Canada Graduate Scholar.

Stanley Fish, "Mission Impossible: Settling the Just Bounds Between Church and State" (1997) 97:8

Colum L Rev 2255 at 2272. 
They do protect people from certain kinds of threats. But equally (or more) important, boundary-setting rights protect people from the seemingly overwhelming responsibility that would flow from a recognition of unity. ${ }^{2}$

Normally, the interaction between law and religion is analyzed as a competition between legal rights and an abstract theoretical discussion of "law" and "religion."3 There is another dimension to the interaction, however, which can be seen in terms of community. The dispute over the creation of a law school at Trinity Western University (TWU) is a rich example of this communal dimension of the interaction between law and religion.

TWU is a private evangelical Christian university that is closely affiliated with the Evangelical Free Church. ${ }^{4}$ Students attending TWU are required to sign a code of conduct, called the TWU Community Covenant Agreement, which is grounded in Protestant values and theology. ${ }^{5}$ In June 2012, TWU began the process of opening a law school, which has generated a significant amount of conflict throughout the Canadian legal community.

The conflict arising from the encounter between TWU and the legal establishment is not simply about whether freedom of religion guarantees TWU a space at the table of legal education, or whether the principle of non-discrimination requires TWU to shed its Covenant. No doubt this plays an important role in the dispute. But I believe that the more pressing questions are about the process involved in integrating TWU, as a religious community, into the community of law's institutional network.

TWU's proposed law school has led to litigation with three different law societies in Canada who refused to accredit TWU's proposed law school. ${ }^{6}$ Even though these law societies are the active parties in the lawsuits, they are not the only ones involved in the conflict. TWU's primary concern is to open a law school, and the litigation with the law societies over accreditation is the means by which TWU seeks to have its proposed law school recognized as legitimate throughout Canada. The recognition that TWU seeks has

Jennifer Nedelsky, Law's Relations: A Relational Theory of Self, Autonomy, and Law (Oxford: Oxford University Press, 2011) at 116.

3 Benjamin L Berger, Law's Religion: Religious Difference and the Claims of Constitutionalism (Toronto: University of Toronto Press, 2015). Berger observed that the interaction between law and religion begins either with the law or with theory (ibid at 23-35). I agree with Berger that both starting points are insufficient.

4 TWU was founded by the Evangelical Free Churches of America (EFCA) in 1962, and continues to be closely connected to both the EFCA and the Evangelical Free Churches of Canada (EFCC). The EFCA and EFCC provide financial support to TWU. Under TWU's bylaws, the president of the EFCA and the executive director of the EFCC are automatic members of the TWU Board of Governors. TWU follows the statement of faith of the EFCC and EFCA, and broadly shares the religious ethos of these organizations. See Trinity Western University v The Law Society of British Columbia, 2015 BCSC 2326, 392 DLR (4th) 722 [TWU BCSC] (Affidavit of William (Bill) Taylor, filed 18 December 2014). Trinty Western University, "Trinity Western University Community Covenant Agreement," online: $<$ www.twu.ca/governance/presidents-office/TWU-community-covenant-agreement.pdf $>$ [TWU, "Covenant"].

6 At the time of writing, trial and appeal decisions have been rendered in British Columbia (TWU BCSC, supra note 4, aff'd 2016 BCCA 423, 405 DLR (4th) 16), Ontario (Trinity Western University v The Law Society of Upper Canada, 2015 ONSC 4250, 126 OR (3d) 1 [TWU ONSC], aff'd 2016 ONCA 518, 131 OR (3d) 113 [TWU ONCA]), and Nova Scotia (Trinity Western University v Nova Scotia Barristers' Society, 2015 NSSC 25, 355 NSR (2d) 124 [TWU NSSC], aff'd 2016 NSCA 59, 376 NSR (2d) 1). The courts in British Columbia and Nova Scotia decided in favour of TWU, while the courts in Ontario decided in favour of the Law Society of Upper Canada. Leave to appeal to the Supreme Court of Canada was granted in both the British Columbia (37318) and Ontario (37209) actions on 23 February 2017, including an order to hear the cases together. 
brought it into conflict just as much with other law schools as it has with the law societies. ${ }^{7}$ Likewise, the practicing members of the legal profession have been a significant source of opposition to TWU's proposed law school. ${ }^{8}$

This varied group of law societies, law schools, legal academics, and practitioners has been bounded together in its opposition to TWU's proposed law school. The way in which they join together, in and through their opposition to TWU, is one of the most fascinating features of the dispute over the proposed TWU law school. Opposition is not always expressed as a full bore rejection of TWU's proposed law school. Many would rather see the removal of TWU's Covenant, or to have the Covenant made optional for TWU law students. Despite the variability in what a preferred result might look like, the shared concern regarding the implications of accrediting TWU's proposed law school for the identity and integrity of the legal profession has crystallized a sense of common identity among those who oppose TWU's proposed law school. It is this emerging conglomerate that I refer to as the "community" with which TWU is in conflict. ${ }^{9}$ Part of what we have to account for when thinking about the TWU law school case is the way that this community forms through the conflict provoked by TWU's proposed law school. I will do this by exploring two elements of this nascent community - its boundaries and its ethos.

In Part II of this article I develop a conceptual understanding of communities in relation to their boundaries in order to frame the conflict between TWU and the legal community. I argue that a community and its boundaries cannot be thought of as rigid and impermeable "things" existing on their own. Rather, they appear through the interaction with other communities and the struggle over the boundaries between them. The creation of boundaries, of defining what is "inside" and "outside" of a community, is actually a process of stitching together the "inside" and the "outside." It is through the conflict occurring at the point of meeting between TWU and the law societies, when TWU attempts to join in the process of legal education, that the boundary of the community of the legal profession takes shape.

In Part III, I discuss the ethos of the legal profession and its relation to the discipline of law school. I argue that they are intricately connected, and that to separate them leads to problems. Those who oppose accrediting TWU tend to see law school and the ethos of the legal profession in terms of objectively defined fundamental values, which leads to the separation between the legal profession and other forms of human experience (like religion). TWU's proposed law school challenges this view, proposing the reconnection of religious and professional life. I argue that TWU also challenges the view of community that allows the ethos of the legal profession to be separated from its disciplinary practices. The differences between TWU and its detractors, primarily the law societies, are not so much a

7 Law students and law professors were quite vocal in their opposition to TWU's proposed law school, which can be seen, for example, by perusing the public submissions to the Nova Scotia Barristers' Society, online: <www.nsbs.org/twu-public-submissions>. The Council of Canadian Law Deans (CCLD) also expressed concern regarding TWU's proposed law school, which is discussed in Part III.B, below.

8 This is most apparent in British Columbia, where the members of the law society voted in a referendum overwhelmingly to refuse to accredit TWU's proposed law school. See Law Society of British Columbia, News Release, "Proposed TWU Law School Not Approved for Law Society's Admission Program" (31 October 2014), online: <https:/www.lawsociety.bc.ca/about-us/news-and-publications/ news/2014/proposed-twu-law-school-not-approved-for-law-socie/> I refer to this community as the community of the legal profession, of law, or of the law societies. 
matter of alternative "values" as a matter of alternative ways to conceptualize the life of the legal community as such.

The apparent intractability of the conflict fades away if the communal lives of TWU and the law societies are set within the context of the process of social interaction that gives shape to each community. From this view, the discipline of law school is dialectically related to the values of the legal profession, and the ethos of the legal profession is tied to the boundary interactions that define the shape of the legal community. The process that shapes community links TWU with the legal profession. The two exist as they do because of their interaction with each other, shaping and transforming each other in the process of their interaction. The boundary that exists between them is constantly evolving.

The dispute over the accreditation of TWU's proposed law school points us down a new and productive path for law and religion scholarship, which is based on the nature of the social interactive processes in which the conflicts between law and religion occur.

\section{Boundaries AS Symbolic MeANing}

The law societies are confronted with the entrance of TWU into the community of the legal profession via participation in legal education. The conflict between them arises because TWU wants to enter into the community that the law societies are guarding. But why is TWU's entrance problematic? This question can be answered by beginning with an analysis of the process that occurs in the interaction between communities at their boundaries. Stated succinctly, the way in which TWU defines its community is offensive to how the law societies define theirs. Unpacking this (admittedly pithy) conclusion requires three steps.

First, I will look at the way the arguments regarding discrimination gloss over different ideas about the nature of the communities of TWU and the law, and their corresponding perceptions of social reality. This shows that the dispute between TWU and the law societies involves more than disagreement over legal principle: it involves disagreement over the nature of legal and religious communities and what it means for them to interact.

Second, I will look at the idea articulated by Anthony Cohen that community boundaries are symbolic constructions. This casts the conflict between TWU and the law societies in a light that sees the bases for establishing the boundaries between them as defying objective description. From this view, the conflict over TWU's proposed law school is part of a process of creating community boundaries and identity. The communities cannot be deciphered separately from the conflict and interaction, which calls into question the possibility of resolving the conflict through an appeal to objective principles (of law or otherwise). The boundaries produced through the interaction are imbued with symbolic meaning, which allows us to see the meaning of the interaction as open and shared between them.

Third, following Mark Salter, I will suggest that the process of crossing boundaries is best understood through the metaphor of "suturing" rather than the more commonly used metaphor of line drawing. This brings attention to the way that interactions at community 
boundaries expose the foundational assumptions and limitations of community identity and belonging. Communities and their boundaries are not independent and rigidly defined things. They emerge through the interactions between communities, and are deeply ambiguous and porously structured. The conflict encountered when one tries to cross between communities, as TWU is attempting to do by opening a law school, exposes the existential contingency and fragility of both communities. This helps us understand the anxiety caused by TWU's proposed law school. It indicates that both TWU and the law societies are engaged in a common process of forming and maintaining the boundaries of their communities, and that the existence of their communities is interdependent.

\section{A. Discrimination, Coercion, AND THE NATURE OF COMMUNITY}

At the most basic level, the law societies that oppose TWU's law school proposal argue that TWU is discriminatory against LGBTQ individuals because they do not admit to the school those who are unable to agree to follow traditional Christian sexual ethics, which are outlined in the Covenant as being restricted to monogamous heterosexual marriages. ${ }^{10}$ There is also a system of accountability and discipline in place at TWU for students who do not follow the Covenant. ${ }^{11}$

An important piece of historical context which affects the discrimination argument is that in 2001, TWU successfully challenged the refusal of the British Columbia College of Teachers to allow TWU to carry out all aspects of the education of public school teachers. ${ }^{12}$ TWU offered courses but was not able to administrate the required practicum aspect of the education program, which meant that TWU students had to complete their training through a public university. When TWU attempted to take up this final portion of teacher training, the College resisted. The College was concerned that the TWU Covenant's conservative position on acceptable sexual behaviour would negatively affect the ability of TWU graduates to deal fairly with people who deviate from the Covenant's norms. Basically, the concern was that TWU graduates would be insensitive toward or (possibly) discriminate against their future LGBTQ students. The College felt that this risk was mitigated by requiring TWU graduates to complete their training at a secular institution, which exposed them to a non-conservative attitude toward LGBTQ sexuality. The Supreme Court of Canada decided that there was no evidence to substantiate the concern of the College. ${ }^{13}$ Graduates from the TWU education program appeared to be just as capable and sensitive as graduates from any secular institution. The presence of the TWU Covenant did not produce graduates that act bigotedly toward LGBTQ people.

TWU, "Covenant," supra note 5 at $2-4$.

Trinity Western University, "Trinity Western University Student Handbook 2016-2017" at 40-48, online: <www.twu.ca/sites/default/files/student-handbook-2016-2017.pdf>.

Trinity Western University v British Columbia College of Teachers, 2001 SCC 31, [2001] 1 SCR 772 [TWU $v$ BCCT].

Ibid at para 38 . 
Despite obvious similarities, there is one significant difference in the conflict regarding TWU's proposed law school. ${ }^{14}$ That is, the law societies who are resisting accreditation of TWU's proposed law school do not suggest that graduates from TWU will discriminate against LGBTQ people. ${ }^{15}$ Rather, the concern is that TWU, as an institution, discriminates against LGBTQ persons, and that a legal education program in such an institution cannot be accredited. The problem is with allowing an accredited law school to use sexual orientation as a basis for denying admission to the school, or taking disciplinary action against them during their time at the school.

There is a key point made in the TWU $v . B C C T$ decision that speaks to this question of institutional discrimination. The Supreme Court held that the voluntary adoption of a code of conduct by individuals based on religious beliefs while attending a private institution is not sufficient to establish a breach of section 15 of the Canadian Charter of Rights and Freedoms ${ }^{16}$ individuals are free to agree to attend TWU and bind themselves to the Covenant that regulates the behaviour of the members of that community. Even though the Covenant has a negative effect on LGBTQ people who might consider attending TWU, to apply the principle of non-discrimination would undermine the principle of religious freedom.

The law societies have argued that the TWU Covenant is not "voluntary" in the way described in the TWU v. BCCT decision. The Law Society of British Columbia (LSBC), for example, characterizes the TWU Covenant as a way of imposing the religious beliefs of the institution on individuals. ${ }^{17}$ It is seen as not merely a statement of belief but rather a way of regulating individual conduct — in the words of the LSBC, it is not an "inspirational" document but a "command." 18 The TWU Covenant is structured specifically to push people to conform to an evangelical Christian worldview, and uses various forms of institutional power to ensure conformity and socialization.

TWU, unsurprisingly, argues that its Covenant is voluntary, and that the specific groups it affects and the mechanisms of enforcement attached to it do not make it less so. The "coercive" elements decried by the law societies ${ }^{19}$ — both the substance of the Covenant and its enforceability — are embraced by TWU as tools necessary for constructing a community

14 It should also be noted that the landscape of judicial review has changed since 2001. The key shift has been in the standard applied in judicially reviewing an administrative body's decision when human rights are at stake. In TWU $v$ BCCT, ibid, the Supreme Court applied the standard of correctness in reviewing the College's decision (that is, according no deference) on the basis that the College did not have any expertise in considering and balancing questions of human rights. Dunsmuir v New Brunswick, 2008 SCC 9, [2008] 1 SCR 190, signalled a sea change in administrative law, streamlining the analysis for determining the standard of review and establishing a standard of reasonableness, and hence deference, for administrative bodies when interpreting and applying their empowering legislation. The way that human rights are treated also changed under Doré v Barreau du Québec, 2012 SCC 12, [2012] 1 SCR 395, where the Supreme Court said that administrative bodies must take into account and balance Charter rights that are at stake in making an administrative decision. The application of these new administrative law principles has been a central point of disagreement and argument throughout the litigation.

15 See e.g. TWU ONCA, supra note 6 at para 58 Part I of the Constitution Act, 1982, being Schedule B to the Canada Act 1982 (UK), 1982, c 11 [Charter]; TWU v BCCT, supra note 12 at para 25.

17 See TWU BCSC, supra note 4 (Written Argument of the Respondent at paras 399-407, 516-20), online: <https://www.lawsociety.bc.ca/Website/media/Shared/docs/newsroom/TWU-argument-LSBC.pdf $>$ [LSBC Written Argument].

18 LSBC Written Argument, ibid at paras 111-18.

$19 \quad$ Ibid at para 464. 
that is capable of realizing spiritual growth. ${ }^{20}$ The Covenant is understood by TWU to be central to its mission as an institution, fostering purposeful relationships between students, faculty, and staff within the context of a common commitment to a shared understanding of the goals of spiritual and intellectual formation. ${ }^{21}$ It is intended to establish a community with a common focus, strengthening the religious commitment and self-identity of its members. Its purpose is precisely to socialize the members of its community into a thoroughly evangelical Christian perspective. ${ }^{22}$

The key for the law societies, which turns the TWU Covenant from a "voluntary" agreement into something coercive and illegal, is its application within the context of legal education. The argument is that membership in the legal profession is a valuable social commodity, which should be equally accessible to everyone, determined only on the basis of merit. ${ }^{23}$ Just as membership in the legal profession is valuable, so too are the spaces available in law school - the pathway to the profession. The limited space in Canadian law schools makes it quite competitive for prospective students to secure a spot. ${ }^{24}$ Because of TWU's Covenant, persons who (for whatever reason) cannot agree to the TWU Covenant will not have access to those spots. ${ }^{25}$ Some people, who are driven to attain membership in the legal profession, will be forced to bend their own personal beliefs and practices to conform to TWU's Covenant in order to access a spot in law school. In particular, LGBTQ persons will be forced to abandon their identities in order to attend the school. ${ }^{26}$

TWU maintains that the competitiveness of law school admission does not negate the legitimate interest it has in shaping its institution in a specifically evangelical Christian form. The legal profession is no different than the profession of education (dealt with in the TWU $v$. BCCT decision). TWU also argues that the creation of a TWU law school will not negatively affect the opportunities available to people who are unable to agree to the TWU Covenant. ${ }^{27}$ In fact, creating more law school spaces at TWU will make it easier for LGBTQ persons to get into law school. Even though the TWU spots will not be available to LGBTQ people, the creation of these spots will relieve some of the competitive pressure from the other available spots. ${ }^{28}$ In addition, TWU's law school spots represent a very small portion of the total spots available, which means that the restrictions over TWU's spots will not have any significant impact on the experience of most students applying for law school or seeking membership in the legal profession. ${ }^{29}$

In support of this view, TWU points to social scientific research indicating that stronger forms of community commitment, such as strict codes of conduct, tend to produce communities with stronger buy-in from their members. See TWU BCSC, supra note 4 (Written Argument of the Petitioners at paras 384, 412), online: <https://www.lawsociety.bc.ca/website/media/Shared/docs/newsroom/TWU-argu ment.pdf $>$ [TWU Written Argument].

TWU Written Argument, ibid at paras 28-35.

Ibid at paras 384, 412 .

See e.g. Loke v British Columbia (Minister of Advanced Education), 2015 BCSC 413, 332 CRR (2d) 237 [Loke] (Amended Petition, filed 3 June 2014 at para 70). The case was dismissed as moot because the British Columbia Ministry withdrew its approval of TWU's law school after the LSBC decided not to accredit it (Loke, ibid at paras 50-66).

LSBC Written Argument, supra note 17 at paras 83-89.

Producing "two tiers" of access to legal education (ibid at para 534).

Ibid at paras 103, 459-64, 470.

TWU Written Argument, supra note 20 at paras 40-43.

Ibid at paras 307, 363. See also Special Advisory Committee on Trinity Western's Proposed School of Law, Final Report (Ottawa: Federation of Law Societies of Canada, 2013) at paras 52-53, online: $<$ docs.flsc.ca/SpecialAdvisoryReportFinal.pdf $>$ [FLSC, Final Report].

See TWU NSSC, supra note 6 at para 247. 
For the law societies, the precise size of the effect that the TWU Covenant will have on LGBTQ students is not important. What is important is that TWU's law school creates some difference between those who can and cannot agree to the terms of the TWU Covenant, by reserving TWU's law school spots just for those who can. ${ }^{30}$ The differentiating effect of TWU's Covenant, no matter how small, is problematic. Any advantage or disadvantage, or any difference in the process of getting and keeping a spot in law school for LGBTQ persons, taints the entire process of coming to the legal profession. ${ }^{31}$

Here we begin to see the social nature of the dispute come into view. Why is it that the seemingly minor effect of TWU's Covenant on the experience of LGBTQ people pursuing a legal career is so important to the law societies? It is because the threat is not simply about LGBTQ people. The threat is about how legal education and the role of the legal profession in society will be affected by allowing TWU to become part of the lawyer accreditation process.

The fact that the conflict is in relation to legal education is unique because law school acts as a gateway to the legal profession. ${ }^{32}$ Who gets "in" and how they get "in" is vital to the constitution of the community and the service that it provides to society. This is reflected in a much-quoted observation of then-Chief Justice of Canada Brian Dickson: "[T] the profession is determined by the selection process at the law schools." ${ }^{33}$ To allow TWU to become part of the gateway to the legal profession threatens to change the nature of legal education and the legal profession as such. The decision to refuse to accredit TWU protects what the law societies perceive to be the ideal vision of the legal profession (and legal professionals) and the function of the legal profession in society. I will have much more to say about the nature of legal education in the second half of this article. For now I simply want to draw attention to two points. First, the context of legal education heightens the social and communal stakes of the situation. Secondly, the law societies do not offer a clear idea of what the ideal vision of the legal profession is that they seek to preserve, only vague ideas put forward in response to TWU regarding upholding the rule of law and fundamental democratic values, ${ }^{34}$ and equal access to justice and the legal profession. ${ }^{35}$

Social and communal considerations are used fairly consistently by both the law societies and TWU. This can be seen in the way that they justify the constitution of their respective communities. TWU claims that the formulation and enforcement of its Covenant are grounded in the religious character of the institution and used with the intention of furthering

See LSBC Written Argument, supra note 17:

The clear effect of the Covenant is to serve as a barrier to access to TWU's proposed law school for LGBTQ persons, women, common law couples, and those of other faiths or no faith at all. This would have the effect of impeding equal access to law school in the province, and would therefore impede equal access to the legal profession. This self-evidently imposes a discriminatory impact and directly harms those deprived of that equal access (ibid at para 493).

See e.g. Law Society of Upper Canada, "Transcript: Convocation, Public Session" (10 April 2014) at 96-98 (Janet E Minor), online: <www.lsuc.on.ca/uploadedFiles/ConvocationTranscriptApr102014TWU. pdf $>$ [LSUC, "Convocation Transcript"].

32 This is also described as broadly affecting the function of the judicial system. See e.g. LSBC Written Argument, supra note 17 at paras $72-82,518$.

33 Brian Dickson, "Legal Education" (1986) 64:2 Can Bar Rev 374 at 377. Quoted in, for example, LSBC Written Argument, ibid at para 519 and TWU ONCA, supra note 6 at para 131.

LSBC Written Argument, ibid at para 57.

See e.g. ibid at paras $59,74,77,81$. 
its religious mission. ${ }^{36}$ TWU claims that this communal self-definition cannot be censured as "coercive" because it is an aspect of religious freedom protected by law. ${ }^{37}$ Similarly, the law societies claim that their opposition to the TWU law school proposal is grounded in the protection of the integrity of the legal profession and the administration of justice. ${ }^{38}$ They argue that the discriminatory effect of the TWU Covenant would be exacerbated by the law societies accrediting TWU's law school because that would endorse inequality in coming to the legal profession, and inequality, no matter how small, is totally unacceptable. ${ }^{39}$ Deciding to not accredit TWU is not unfair towards TWU (and therefore not "coercive") because it protects the public interest by ensuring that membership in the legal profession is equally accessible to everyone.

Social and communal considerations are also used by both TWU and the law societies in attempting to circumscribe the scope of each other's community, calling into question those considerations that are supposed to justify the actions of the other. TWU argues that law societies are only mandated to regulate the conduct of practicing lawyers, and that they have no role in determining what is permissible in the internal affairs of a university (or a religious institution). ${ }^{40}$ As such, the refusal to accredit TWU's law school on the basis of the TWU Covenant is tantamount to pushing a non-discriminatory agenda in the context of a private and religiously-based university administration. This is an abuse of governmental administrative power, which jeopardizes religious freedom and the rule of law. ${ }^{41}$

The law societies argue that the TWU Covenant is not really a matter of religion, and that there is no religious impetus driving the formation of the law school. ${ }^{42}$ Moreover, TWU is not really a religious institution because it is engaged in the primarily secular endeavour of university education and granting university degrees - and TWU's aspiration to engage in legal education is supremely public and secular. ${ }^{43}$ As such, TWU cannot structure its law school in the same way as more overtly religious organizations (like churches or seminaries). For the law societies, TWU's attempt to push its Covenant into the realm of legal education steps beyond the bounds created for it in the sphere of public education (namely, its exceptional status under BC legislation) — " "[i]n short, effectively prohibiting LGBTQ persons and others from attending TWU law school transforms religious belief into discriminatory conduct." 44

The purpose of highlighting how TWU and the law societies understand the natures of their own and each other's communities shows that there is a dimension to the conflict beyond the principles of equality and religious freedom. The arguments in the lawsuit, and the decisions of the court, also say something about the natures of the communities of TWU and the law societies and the way we characterize and make sense of conflicts between different communities. The resulting gap between TWU and the LSBC (and other law

\footnotetext{
See TWU Written Argument, supra note 20 at paras 32-35, 361, 384, 391, 412.

See ibid at paras 357-62.

LSBC Written Argument, supra note 17 at para 511.

Ibid at paras 508, 511-14, 520, 535-37.

See TWU Written Argument, supra note 20 at paras 254-58, 293-97. See also TWU ONSC, supra note 6 at paras 53-55; TWU NSSC, supra note 6 at paras 166-81.

TWU Written Argument, ibid at paras 187-98, 373-79, 391, 454-55.

LSBC Written Argument, supra note 17 at paras 574-80.

Ibid at para 587.

Ibid at para 446 .
} 
societies) reflects fundamentally different views of social reality. Both TWU and the law societies claim "social reality" really is as they perceive it, and look to establish through litigation their own perception of social reality. What then are we to do with a conflict that is beginning to look more like a matter of choosing between different conceptions of social reality?

\section{B. Constructing Community: Boundaries as Symbolic Meaning}

The arguments put forward by TWU and the law societies are grounded in different ideas about themselves as communities. The central point of disagreement is over the way in which the communities - both TWU and the law societies - keep their boundaries. The study of boundaries and borders is used in a broad range of academic fields (including geography, politics, sociology, anthropology, and economics), in relation to various social phenomena (including national territories, political ideologies, and ethnic and cultural identities), and through a range of evolving theoretical approaches. ${ }^{45}$ The focus here will be on looking at the notion of a boundary in terms of symbolic meaning. This provides a way of understanding the interaction between communities as a means by which a community develops its own identity and perception of reality. From this point of view, the conflict over the accreditation of TWU's proposed law school is formative for the community of TWU as well as for the legal community - their respective identities and perceptions of social reality develop through the interaction with each other because of the fact that they are pressed to define their communities in response to each other.

Anthony Cohen, in his book The Symbolic Construction of Community, ${ }^{46}$ shows that communities are formed through the construction of boundaries, and explains how this is tied to the idea of symbolic meaning. ${ }^{47}$ For Cohen, communities are relational entities. They imply a distinction between "us" and "them," of being inside or outside. "Us" and "them" are intricately related. We are "us" because we are not "them," and they are "them" because they are not "us." This relation is symbolically represented through the boundaries that define community.

Cohen draws out of the relation between "us" and "them" a dual function of boundaries. The boundary that stands between two communities functions both to distinguish between communities as well as to establish unity within a community. Boundaries are able to fulfill this dual function of dividing and unifying because they are symbolic in nature. Symbols do

45 See Vladimir Kolossov, "Border Studies: Changing Perspectives and Theoretical Approaches" (2005) 10:4 Geopolitics 606.

46 Anthony P Cohen, The Symbolic Construction of Community (London, UK: Routledge, 2001).

47 Cohen's book participates in a rich and diverse theoretical discussion of community, symbolic meaning, and boundaries. See e.g. Peter L Berger \& Thomas Luckmann, The Social Construction of Reality: A Treatise in the Sociology of Knowledge (Garden City, NY: Anchor Books, 1967); John R Searle, The Construction of Social Reality (New York: Free Press, 1995); Alfred Schutz, Collected Papers, vol 1, ed by Maurice Natanson (The Hague, NL: Martinus Nijhoff, 1962).

48 Cohen, ibid at 12. There is notable overlap between Cohen's argument and a phenomenological analysis of identity formation. For more on how a phenomenological approach relates to community formation, see H Peter Steeves, Founding Community: A Phenomenological-Ethical Inquiry (Dordrecht, NL: Springer, 1998). 
not directly represent what they signify, and they do not provide their own meaning. Symbols are tools by which meaning can be made. ${ }^{49}$

The creation of community is, for Cohen, primarily a task of gathering diverse individuals together under a common banner. The symbolic meaning of a boundary allows this to occur because the meaning of a symbol is naturally ambiguous. ${ }^{50}$ The ambiguity of symbols allows individuals to give meaning to them in a manner consistent with their own personal experiences. Different people are able to gather together and identify themselves as "us" under the banner of a common symbol. It is not necessary for everyone to understand the symbol as having the same meaning, only that they are all committed to using it as a part of their own lives and as a marker of their own identities. This, for Cohen, is how community comes into being. Its triumph is that it is able to hold together diverse individuals under a single symbolic boundary. ${ }^{51}$ Community boundaries aggregate social differences. ${ }^{52}$

The ambiguity of meaning inherent in boundaries complicates the way we conceptualize the identity of a community. Although the boundary makes the community appear as a coherent whole, it does not have a single meaning even for those within the community. ${ }^{53}$ The boundary masks the diverse views of the nature of the community that coexist internal to the community itself. Even the self-understanding of a community defies an objective grounding point. Since boundaries are central to the way that a community understands itself, there is a necessary element of openness to community. A community is not defined entirely internal to itself, but reflects the encounters with "other" communities as well as the larger set of social relations of which the members of a community are a part.

At the end of the previous section I suggested that the conflict between TWU and the law societies seems to take the shape of a competition between two conceptions of social reality seeking to establish the "truth" of the situation. Cohen's argument regarding the symbolic meaning of community boundaries focuses on the process of community development. In light of Cohen's argument, the encounter between TWU and the law societies should not be conceptualized as between two rigidly defined communities with fully formed ideas about their nature. The images of the communities that we can see represented in the legal arguments are the "boundaries" that emerge through the interaction between TWU and the law societies.

However, at the same time, we cannot forget that these boundaries operate symbolically, which means that although they are shaping the communities, they do not actually have a clear and distinct meaning on their own. What I mean is that the conflict helps to give shape to the communities and the way they understand themselves. To see each community as fully

Cohen, ibid at 12, 15, 19.

Ibid at 21 .

Ibid at 20. See also Roger Cotterrell, Law's Community: Legal Theory in Sociological Perspective (Oxford, UK: Clarendon Press, 1995) at 322-25. Cotterrell argues that employing the notion of community within the context of law implies a concern for social diversity, for the primacy of the local, and for moral pluralism.

52 See Cohen, ibid at 20-21. Cohen proposes aggregation rather than integration as a way to distinguish his theory from other theories of social organization derived from Émile Durkheim. Aggregation is preferable to integration because the former allows for difference and diversity to persist within social formations of community, whereas the latter tends toward homogenization. Ibid at 58 . 
formed fails to recognize the symbolic nature of their boundaries, and leads to the view that the conflict can only be resolved by choosing between them. Cohen's point of view would suggest, to the contrary, that the encounter between TWU and the law societies helps produce their boundaries. It is in meeting each other, in conflict and interaction, that the selfperception of each community and of social reality takes shape.

The interaction between TWU and the law societies cannot be expressed in a single dimension. The conflict is not simply about the nature of legal education or the ideal vision of the legal profession. The same can be said for many of the other points of dispute, such as the nature of religious freedom, the extent of the administrative powers of the law societies, the character of TWU's university community, and so on. As TWU and the law societies engage with each other about these issues, their self-understandings of the nature of their communities are sharpened. At the same time, the self-understandings of TWU and the law societies are not only tied to each other, but also to the many other social relationships that each community understands itself to be part of. For example, when TWU argued that the Covenant is central to its character as a Christian university, it drew on its relationship with the larger (global) evangelical Christian community ${ }^{54}$ Similarly, the law societies understand themselves to be in close relation with law schools, which are intricately involved in the realization of the rule of law, the administration of justice, the integrity of the legal profession and the institutions of the legal system (including the judicial branch), and the advancement of individual dignity. ${ }^{55}$

Two points flow from this. First, it is important to keep in mind that both TWU and the law societies house a diverse array of opinions on the nature and meaning of the conflict, despite what is represented by the "official voices" of each community. Secondly, we should be very cautious about trying to resolve the conflict by deciphering the "true" nature of the communities or of the boundaries of the communities.

Cohen's argument stands as a warning against aligning the identity of a community with the appearance of its boundary. Even though the boundary is a key part of how the community understands itself and, in a way, is the basis on which the community exists, it is nevertheless a thoroughly symbolic creation and therefore subject to change. The boundary of a community, its idealized self-conceptions, and indeed the community itself are permeable. In the TWU situation, this refers to the ideal conceptions of each community. To understand the nature of each community it is necessary to see each in relation to the other. TWU and the law societies need to be seen as mutually constituting each other through their interactions. Without their interactions with each other, neither community would appear as it does. In this way, the "us" and the "them" are interdependent. ${ }^{56}$

This does not dissolve the differences between TWU and the law societies or negate that they are distinct communities. Rather, it complicates the way that we understand the interaction between them and the community formations that emerge from their interaction. For Cohen there is an element of openness to community, which is grounded in the way that

TWU Written Argument, supra note 20 at paras 15-19.

See e.g. LSBC Written Argument, supra note 17 at paras 32, 56, 77, 88-89, 302, 444, 510, 520-21.

Anastassia Tsoukala, "Boundary-Creating Processes and the Social Construction of Threat" (2008) 33:2 Alternatives 137 at $140-42$. 
different meanings can be given to boundaries. Although the interaction helps give shape to boundaries, this does not negate or destroy the openness of the boundaries.

\section{The Foundations OF CoMmunity: BOUNDARY CROSSING AS "SUTURE"}

There is a risk in emphasizing the ambiguity of symbols and the resulting openness of community boundaries. Doing so might render innocuous the conflict that occurs between communities. Cohen is certainly right to say that the symbols that shape communal identity can be shared and altered by different individuals and different communities. It is therefore important to emphasize that the presence of common symbols between communities does not lead to the homogenization of meaning, but enables the coexistence of diversity. ${ }^{57}$ Community is constituted by boundaries that work to hold together a diverse group of people through the flexibility of their meanings.

However, the interaction between communities shows that boundaries, despite their ambiguity, operate as though they have a definitive meaning. This can be seen in the TWU situation. The boundary drawn by the law societies that oppose TWU's law school, even though imbued with symbolic meaning, does not appear to be amenable to the adaptation, digestion, and reassignment of meaning that Cohen's analysis implies. ${ }^{58}$ It seems that the potential for diversity to coexist has a limit.

How then are we to make sense of the concomitance of ambiguity and firmness in community boundaries? An important first step is to move away from seeing boundaries as lines of separation. The metaphor of a line draws a hard distinction between what it means to be "inside" and "outside" of a community, which restricts the view of a conflict to exploring the points of view of each community. ${ }^{59}$ This is not to say that the experiences of people belonging to the different communities are unimportant, but it is impossible to identify a coherent single experience or point of view that represents a community. Focusing on boundaries as lines not only leaves us with an inaccurate perception of the communities in question (as argued in the previous section), but also hampers our ability to grasp the way that boundaries relate to the interaction between communities, and the way in which the selfunderstanding emerging from this interaction operates as a process. ${ }^{60}$

Mark Salter proposes the metaphor of "suture" for making sense of the process of crossing community boundaries. ${ }^{61}$ Salter sets out to explore the "/" that lies between inside/outside. In other words, what happens when someone on the outside comes to the boundary of a

Cohen, supra note 46 at 44.

See ibid at 46, where Cohen uses the metaphor of digestion.

Mark B Salter, "Theory of the / : The Suture and Critical Border Studies" (2012) 17:4 Geopolitics 734 at 737 .

There are other ways to imagine boundaries, such as in terms of "lines" and "spaces." See e.g. Zenon Bańkowski \& Maksymilian Del Mar, "Images of Borders and the Politics and Legality of Identity" in Richard Nobles \& David Schiff, eds, Law, Society and Community: Socio-Legal Essays in Honour of Roger Cotterrell (Farnham, UK: Ashgate, 2014) 61. For more on the shift to thinking of law in terms of "process," see James MacLean, Rethinking Law as Process: Creativity, Novelty, Change (Abingdon, UK: Routledge, 2012).

61 Salter, supra note 59. Although Salter's discussion focused on individuals crossing state borders, his insights are relevant for understanding the process of crossing boundaries more generally. 
community and tries to come in? Not satisfied with descriptions of a boundary as a point or line of division, he seeks to articulate the "/" in terms of a process of inclusion and exclusion. ${ }^{62}$ Using the metaphor of "suture," he argues that the process occurring at the boundary is a cut, or a rupture, and then a stitching together. From this view, boundaries are not points of separation between communities, but dynamic points of opening and closing that join together the inside and the outside. They provide the conditions for the possibility of communal existence. ${ }^{63}$

Salter uses the example of an individual crossing a state border. When crossing a border an individual must show her credentials of identity from her original community. The person's right to belong and come into the new state is not guaranteed, but depends on the sovereign decision of a community to accept her. The relationship between an individual and her community is ruptured and exposed as neither natural nor permanent, but rather constructed and contingent. This rupture, or cut, threatens the existence of the community because community depends upon individuals who see themselves and their identities as constituted, at least in part, by belonging to the community. ${ }^{64}$

The reason that the cut does not destroy the community is because the cut is portrayed as an exception to the otherwise smooth continuity of identity in the community and the strength of the community's borders. ${ }^{65}$ This narrative conceptualizes the community as a coherent entity that has the power to exclude and include individuals. In order for the individual crossing the boundary to enter the community, she must internalize the narrative of community existence and power. It is through the individual internalizing the narrative that the community really comes to life. The community appears as "real" and "powerful" because the individual accepts that it is so. Ironically, it is through the individual internalizing the community that the cut in the community's boundary is pulled closed. ${ }^{66}$

There are two things exposed by this process. First, that the integration of an individual into a community - the act of suturing the boundary closed, of actually creating the community - depends on the individual internalizing the narrative of the community's authority to determine individual belonging. Secondly, the authority and power of the community is limited. Belonging to one community does not guarantee that an individual can belong to another community. Belonging to a community is only ever a temporary thing.

Salter argues that while inside of a community it is easy not to see this process of creating and affirming boundaries. But when someone crosses a border, then the foundations of the community come into view. Opening and closing the question of identity in a community exposes the foundation of the very existence of the community. ${ }^{67}$ Communities need to exclude (externalizing the individual and other communities) because the power of the community depends on individuals who are "outside" to accept and internalize the narrative establishing the existence, power, and authority of the community as they move "inside." 
The inside and outside of a community are simultaneously "made strange and knit together." ${ }^{\prime 68}$ Crossing boundaries is a way of stitching together the outside and inside. ${ }^{69}$ The disruption caused by a border crossing is part of the process by which the community expresses its power and constitutes itself. By exposing its own limits, a community exposes the power by which it holds itself together. ${ }^{70}$

In a similar way, the interaction in the TWU situation should not be seen only in terms of disagreement or conflict about some object. Rather, TWU is trying to cross over the boundary and integrate itself into the community of the law societies. The interaction at the boundary between TWU and the law societies exposes a process by which both TWU and the law societies constitute themselves as communities. In theoretical terms,

[t]he suture connects the two spheres of possibility in part by making visible the dividing line between the spaces, but also insisting on its own presence and character as an exception.... The suture is pregnant with meaning - not only by what it creates and separates, but also in the way that it connects and distinguishes. It renders visible the raw power that must be exerted to hold the two together and apart. ${ }^{71}$

The LGBTQ person who seeks to enter the TWU community has to internalize the TWU community as a community with integrity, and to conform himself or herself to the narrative of TWU's institutional existence. But this is no different than any other individual coming to join the community. Integration into the community requires leaving behind that which does not fit, and conforming oneself to the perspective embodied by the community. For TWU, this includes the norms of the community as well as the discourse on which those norms are based.

The very same process can be seen in the law societies. In order for TWU to enter the "community" of the law (to open a law school) it must internalize the norms and the narrative that sustains the community. According to those opposed to accrediting TWU's proposed law school, the community of the legal profession is grounded in the fundamental norm (or value) of equality. The process of coming to the legal profession protects the legal profession and enables it to fulfill its social role, which is to sustain the integrity of Canada's legal institutions.

The claims of both TWU and the law societies are grounded in idealized conceptions of the integrity of their communities. Both are also sustained by a common process — both depend on the "other," who is outside, to internalize the narrative that holds their communities together. By claiming the same power to exclude people from belonging to their communities they show that belonging to either community is at best an incomplete and temporary thing. Calling into question each other's power of integration and exclusion exposes the limitations of the powers of each community in relation to those on the outside. The communities are proven to be, on their own, somehow emptier than we might expect.

$69 \quad$ Ibid ("The border is at once a division and a knitting together of legal spheres, sovereignties, and authorities" at 750).

70 Ibid at $739-40$

71 Ibid at 740 [footnote omitted]. 
Their existence depends on the interaction with other communities and the process of integrating individuals into their communities.

The interaction between TWU and the law societies puts into question the ideal forms of community imagined by TWU and the law societies. If we take the points raised by Cohen and Salter seriously, we cannot allow the conflict between TWU and the law societies to be determined solely in terms of the "integrity" of the communities. Even though the idealized vision of community operates as a key part of the foundation of community, these community ideals must be seen within the context of the community formation process.

It is difficult to know what it would look like to integrate TWU and the legal community because this involves a complex process of defining, transforming, challenging, and accepting the boundaries of both communities. The flexible and fungible nature of boundaries allows a measure of dissonance to be present in TWU's participation in the legal community. Allowing TWU to participate in the legal community would undoubtedly change the legal community and the TWU community.

It may well be that the changes to the legal community brought about by TWU's proposed law school threaten certain conceptualizations of the legal community (namely, the idea of the legal community championed by the law societies). However, this threat points to the existential limitations of the legal community as such. That is to say, the legal profession does not exist "out there" with integrity to be protected and kept intact. In fact, the discomfort felt in the struggle to determine how to stitch TWU into the community of the legal profession is part of the very foundation of the community of the legal profession itself. The community of the legal profession only exists insofar as communities like TWU are external to it and can internalize it. The same could be said for TWU. The threat felt over the prospect of giving up the TWU Covenant is a reflection of the existential limitations of the TWU community. The threat felt by TWU and the legal community is the visceral experience of the social process by which each of these communities is formed and evolves.

Evaluating the process of the integration of TWU's proposed law school into the community of the legal profession in order to make a judgment about accrediting the school is deeply affected by the way that the community of the legal profession is conceptualized. In what follows, I will look at the current conceptualization of those who oppose accreditation of TWU's proposed law school, and how this affects our ability to evaluate TWU's move to join the legal community. I argue that it is necessary to open up the way that we think about community (of the legal profession or TWU) to a broader range of social, historical, and discursive factors than what has been engaged so far. On this basis, even without giving a final answer to the question of whether TWU's proposed law school can be accredited, we are able to see that the arguments used so far to refuse accreditation are insufficient.

\section{ETHOS AND DISCIPLINE}

We have already seen that the integrity of the legal profession is somehow tied to the process of admission to law school. Those opposed to accrediting TWU's proposed law school describe this connection in terms of a shared "ethos" grounded in the value of 
equality. They argue that to accredit a law school at TWU that includes the Covenant would corrode the "ethos" of the legal profession.

To perceive TWU's proposed law school as a threat to the ethos of the legal profession presumes not only that the legal profession and legal education are a single community with a shared "ethos," but also that this ethos persists in a certain form. Specifically, as will be discussed below, those who oppose the accreditation of TWU's proposed law school conceptualize the ethos of the legal profession as an essence defined by fundamental legal values that are distinct from the actual practices of institutions and individuals.

I will argue here that the primary problem with defining the ethos of the legal profession in this way is that it separates the ethos from the practices of the legal profession. Determining whether the TWU Covenant is compatible with the ethos of the legal profession requires either identifying the values of the TWU Covenant and finding them inconsistent with the ethos of the legal profession, or finding that the practice of the Covenant is inconsistent with practices acceptable to the ethos. In either case it is necessary to answer why and how certain values come to be fundamental to the ethos of the legal profession, and how these values relate to particular practices (like the TWU Covenant). It is impossible to know how and why values become authoritative for a community, and how these values shape the practices of a community, without being able to connect those values to the practices of community occurring in its social, historical, political, and discursive evolution.

Severing the connection between the fundamental values and the practices of the legal profession makes it difficult to justify why the ethos of the profession aligns with certain values (such as the value of equality) and not others. Losing a sense of how the ethos of the community emerges through the practices of the community (social, discursive, or otherwise), we are left with the assertions made by the already established community about the nature of its ethos. The community simply is what it is, and to be part of the community depends upon simply accepting it as it has been presented.

This raw choice is not acceptable for a number of reasons. Primarily, it fails to account for the complex social interactive process by which communities take shape. As was argued in the first half of the article, communities are not things that simply exist "out there," but are rather inextricably tied to a complex social interactive process involving a dynamic interplay between communities and individuals. Alienating the meaning of the ethos of the legal profession from the institutional practices of the professional community by defining ethos solely in terms of fundamental values provides an impoverished view of the community. It disregards the way that community boundaries are shaped through social interaction, it does not account for the influence of communities on each other, and it does not consider the role of the individual in constituting the community as such. The ethos of a community, ultimately, is the product of these processes. The discussion of the ethos of the legal profession in relation to TWU's proposed law school requires a more robust understanding of "ethos": one that takes into account the relation between the values and practices in the construction of community.

In what follows, I will look at how the notion of the "ethos" is employed by the law societies and the Ontario courts, drawing particular attention to the way that "fundamental 
values" are given a central place in defining that ethos. I will then look at the disciplinary practice of law school, which sheds light on why the ethos of the legal profession is conceptualized in terms of fundamental values. The separation between values and practice is part of the practice of the discipline of law school. The tacit knowledge engendered in law school shapes individuals who are dependent upon the community of the legal profession by separating the legal part of their selves from the other aspects of their lives. In the final section I will consider the nature of the challenge that TWU's proposed law school puts to the legal profession. This challenge is best understood not as a conflict between alternative core values, but rather as a call to reconnect values to practice in defining the ethos of the legal profession.

As we saw in the first half of the article, there is a dynamic tension between the open and closed aspects of community. My argument here seeks to affirm, not deny, this tension. The discipline of law school, and the ethos of the legal profession, is not to be abandoned, but must be put into the context of its underlying dynamic social interactive processes.

\section{A. "The Ethos of the Legal Profession": VALUE OR VIRTUE?}

The Oxford English Dictionary defines "ethos" in one sense as, "[t]he characteristic spirit of a people, community, culture, or era as manifested in its attitudes and aspirations; the prevailing character of an institution or system."72 "Ethos" is that which most deeply permeates a community. There is no question that the ethos of the legal profession is relevant for thinking about legal education and, specifically, TWU's proposed law school. The difficulty, though, is the way in which ethos is conceptualized and used.

How then should the "ethos" of the legal profession be understood in relation to legal education, and how is it related to the dispute over the accreditation of TWU's proposed law school? The idea of "ethos" was brought to bear on TWU's proposed law school through reference to a speech given years ago by Brian Dickson, the former Chief Justice of the Supreme Court of Canada, on legal education. It is worth reproducing the context surrounding Dickson's reference to the "ethos" of the legal profession:

I want to say a few words about the gatekeepers to legal education, namely those involved in the admissions process. Those who fulfil this role are, in a real sense, the gatekeepers of the legal profession. Ultimately, the ethos of the profession is determined by the selection process at the law schools. In order to ensure that our legal system continues to fulfil its important role in Canadian society, it is necessary that the best candidates be chosen for admission to law schools. By "best" I mean more than just the most academically qualified. I also mean young people who exhibit other qualities such as compassion, unselfish service to their community and idealism.

Furthermore, it is incumbent upon those involved in the admission process to ensure equality of admissions. For a long time, law, like other professions, was a male profession. In the last decade great strides have been taken to overcome this problem. A large number of women have been admitted to Canadian law schools, have performed superbly there, and are now embarking upon successful legal careers which will, inevitably, lead 
them to the pinnacles of the practicing and judicial branches of the profession. Now, it seems to me, we must devote our energies to ensuring that there is a high degree of sensitivity in our admissions programs to those from different ethnic and economic backgrounds. Canada is a country which prides itself on adherence to the ideal of equality of opportunity. If that ideal is to be realized in our profession then law schools, and ultimately the legal profession, must be alert to the need to encourage people from minority groups and people from difficult economic circumstances to join our profession. ${ }^{73}$

The connection Dickson drew between legal education and legal practice is not original. The debate about the nature of legal education, and how it connects to the professional practice of the law, is ongoing. ${ }^{74}$ For Dickson, those involved in determining the selection process at law school are the "gatekeepers" of the legal profession, and the significance of their task should not be taken lightly. What happens in law school, including the process by which people are admitted to law school, affects the body of practicing lawyers and the other institutions of law. By invoking the notion of "ethos" to establish the connection between legal education and the legal profession, Dickson brings to our attention that legal education does more than simply deliver legal information. It has an important social role: participating in constituting the culture of the legal profession.

Those opposed to accrediting TWU's proposed law school gravitate to Dickson's reference to equality. ${ }^{75}$ Equality is particularly important because many of the law societies are charged in their enabling statutes to uphold the rights and freedoms of everyone, which implies the duty to uphold the principle of legal equality in some measure. ${ }^{76}$ It is argued that the inconsistency between the TWU Covenant and the evolving principles of law in Canada regarding non-discrimination towards sexual minorities makes TWU's proposed law school inconsistent with the "ethos" of the legal profession and, on that basis, not fit for accreditation. The gatekeeping role of the law school should be exercised in a way that reflects Canadian law, and specifically the laws of equality and non-discrimination. ${ }^{77}$

Linking law school and the legal profession through an ethos of equality magnifies the potential effect that accrediting TWU's proposed law school might have on the legal profession. TWU's Covenant would change the normal process of entering law school.

Dickson, supra note 33 at 377 [emphasis added to indicate what has received the most attention]. Terrance Sandalow, "The Moral Responsibility of Law Schools" (1984) 34:2 J Leg Educ 163. Some scholars think that the legal academy is primarily a professional discipline, and that it should conform to the needs, ideals, and values of the profession: see e.g. Harry T Edwards, "The Growing Disjunction Between Legal Education and the Legal Profession" (1992) 91:1 Mich L Rev 34. Others argue that legal education is a unique academic discipline with its own ideals, values, and ambitions: see e.g. Stephen M Feldman, "The Transformation of an Academic Discipline: Law Professors in the Past and Future (or Toy Story Too)" (2004) 54:4 J Leg Educ 471; Mary Ann Glendon, "Why Cross Boundaries?" (1996) 53:3 Wash \& Lee L Rev 971; Cass R Sunstein, "In Defense of Liberal Education” (1993) 43:1 J Leg Educ 22; J Peter Byrne, "Academic Freedom and Political Neutrality in Law Schools: An Essay on Structure and Ideology in Professional Education" (1993) 43:3 J Leg Educ 315; Sherman J Clark, "Law School as Liberal Education" (2013) 63:2 J Leg Educ 235. In either case, the connection between the academic and the professional aspects of legal education is irrevocable, and the tension that this union produces gives legal education a particular (and resilient) shape: see e.g. Edward L Rubin, "The Practice and Discourse of Legal Scholarship" (1988) 86:8 Mich L Rev 1835.

See e.g. LSBC Written Argument, supra note 17 at para 81.

See Nova Scotia's Legal Profession Act, SNS 2004, c 28, s 4(1); Ontario's Law Society Act, RSO 1990, c L.8, s 4.2; British Columbia's Legal Profession Act, SBC 1998, c 9, s 3.

The LSBC relied on this argument in its litigation with TWU (LSBC Written Argument, supra note 17 at paras 72-82). The Ontario Court of Appeal also relied on the same idea in finding against TWU (TWU ONCA, supra note 6 at para 132). 
Rather than judging student admission to law school solely on the basis of merit, ${ }^{78}$ the TWU Covenant makes the beliefs and practices of students, including those regarding sexuality, central to membership in a community of legal education. Aligning the ethos of the profession with equality means that the change represented by the TWU Covenant will reverberate throughout the entire legal profession. Accrediting TWU's law program would be hypocritical for the law societies and inconsistent with the character of the profession. ${ }^{79}$ Accreditation would undermine "the integrity of our legal system and hence public confidence in the administration of justice." 80

Linking the ethos of the legal profession to equality in this way misses a key component of Dickson's argument. It is true that Dickson encourages equality in law school admissions, and believes that legal education should be made more available to people who are marginalized. But equality, for Dickson, does not mean that nothing is relevant to admissions other than merit. Rather, Dickson argues that choosing the "best" candidates for law school means to choose applicants with character traits "such as compassion, unselfish service to their community and idealism." ${ }^{\text {" }}$ This is necessary for law school to achieve its primary purpose, which Dickson describes as "to train for the legal profession people who are, first, honest; second, compassionate; third, knowledgeable about the law; and fourth, committed to the role of law and justice in our democratic society." 82 Increasing access to legal education on the basis of non-discrimination is ancillary to his primary concern, which is to foster a virtuous profession, using legal education to develop virtuous character in its future professionals.

It is telling that Dickson's reference to virtuous character was excluded from the quotations of him used in both the trial and appellate decisions of the Ontario courts (both which found against TWU's argument) ${ }^{83}$ Similarly, the LSBC mischaracterized Dickson's idea of the primary purpose of legal education as "ensur[ing] a commitment to the fundamental values of our society." 84 The LSBC uses the "fundamental values of society" to say that the role of the gatekeeping function of law school admissions is to protect against discrimination. ${ }^{85}$

Dickson's description of legal education and its relation to the "ethos" of the legal profession does not look to "fundamental values of society." Looking instead to character and virtue, with the hope that law school admissions can be used to transform the legal profession into a virtuous profession, Dickson provides a different view of the priorities of admissions to law school. The primary focus of law school admissions should be on stocking the law schools with good people and on making sure that law schools produce good lawyers of high character. Focusing on the virtues and character formation of individual professionals is presumptively open to the use of moral and behavioural standards in the process of

\footnotetext{
78 TWU ONSC, supra note 6 at para 97; TWU ONCA, ibid at paras 109, 112. See also LSUC, "Convocation Transcript," supra note 31 at 95-96 (Janet E Minor).

See TWU ONSC, ibid at para 118.

LSBC Written Argument, supra note 17 at para 89.

Dickson, supra note 33 at 377.

Ibid at 376.

TWU ONSC, supra note 6 at para 98; TWU ONCA, supra note 6 at para 131.

LSBC Written Argument, supra note 17 at para 78.

Ibid at para 82 .
} 
determining admissions to law school. This is not to say that an approach based on virtue would support TWU's Covenant and its view of human sexuality. But things like sexual practice and religious beliefs could not be disregarded out of hand as irrelevant to shaping a virtuous professional and, therefore, a virtuous profession. Instead, from this perspective, TWU's Covenant should be evaluated in terms related to the development of character and virtue, on what makes an individual virtuous in the ways that lawyers should be virtuous which Dickson identifies as honesty, compassion, and an attitude of community service. ${ }^{86}$ Rather than "fundamental values," the discussion would be about the purposes and ends of the legal profession, and how these purposes and ends are embodied in the lives of legal professionals. ${ }^{87}$

It is precisely on the point of what types of people TWU's proposed law school will produce that the argument against accrediting TWU's proposed law school finds its limit. Following the reasoning in TWU $v$. BCCT, it is not valid to claim that the discriminatory nature of TWU's Covenant will produce people with character disposed toward discrimination. The law societies who oppose accrediting TWU's proposed law school recognize this, and consistently say that their decision to not accredit is not grounded in the actions of prospective graduates from TWU. Non-accreditation is instead focused on the institution of TWU - specifically the TWU Covenant. ${ }^{88}$ In other words, refusing to accredit TWU's proposed law school is decidedly not about the formation of virtuous character through legal education. It is about defining and reinforcing values that persist on an institutional level separate from the individual lives of the members of the institution.

One of the difficulties with characterizing the ethos of the legal profession in this way is the abstract nature of fundamental values. This is especially so in relation to the value of equality. The Charter, which protects against discrimination, has been referred to as a source of the fundamental values of Canadian society. ${ }^{89}$ But the Charter, of course, protects both equality and religious freedom. ${ }^{90}$ It is not possible to rely on the Charter to ground the ethos of the legal profession in the value of equality, especially when equality is being marshalled to restrict a religious practice (the TWU Covenant). The various rights and values embedded in the Charter have consistently been interpreted as ordered non-hierarchically and in balance with each other. ${ }^{91}$ From this perspective, the truly "fundamental value" of Canada, vis-à-vis the Charter, is some form of the balancing of rights, not equality (or religious freedom).

86

For another account of the important role of virtue in guiding legal education, see Roderick A Macdonald \& Thomas B McMorrow, "Decolonizing Law School" (2014) 51:4 Alta L Rev 717.

See e.g. Anthony T Kronman, "Living in the Law" (1987) 54:3 U Chicago L Rev 835. For more in-depth discussion of what is involved in relating virtue and character to different practices, see Alasdair MacIntyre, After Virtue: A Study in Moral Theory, 3rd ed (Notre Dame: University of Notre Dame Press, 2007) [MacIntyre, After Virtue], especially ch 14.

See e.g. LSBC Written Argument, supra note 17 at para 417. See also TWU ONSC, supra note 6 at para 115.

Hill v Church of Scientology of Toronto, [1995] 2 SCR 1130 ("[t]he Charter represents a restatement of the fundamental values which guide and shape our democratic society and our legal system" at para 92). Supra note 16. Freedom of religion is protected in section 2(a) as one of the "fundamental freedoms." Religion is an enumerated ground of discrimination in section 15(1). Sexual orientation was read into section 15 of the Charter by the Supreme Court of Canada in Egan v Canada, [1995] 2 SCR 513. See also Vriend v Alberta, [1998] 1 SCR 493.

Dagenais v Canadian Broadcasting Corp, [1994] 3 SCR 835 at 877 (there is no hierarchy of Charter rights, but when rights are in conflict they must be balanced); $R v N S, 2012$ SCC 72, [2012] 3 SCR 726 at paras 30-32 (competing Charter rights must be balanced in order to preserve them both). 
Outside of the context of the Charter, Canadian "fundamental values" have been described as the principles of equality, human rights, and democracy. ${ }^{92}$ But the abstract sense of "equality" listed here lacks the specific content required to succeed in claiming a right to equal treatment in a concrete situation, such as in admission to law school. Equality in its abstract sense is distinct from equality as a legal claim. In its abstract sense, equality is a principle of the rule of law that all are equal before and under the law — that the law should be applied equally to everyone. ${ }^{93}$ As a legal claim, equality relates to the differential application of a specific rule or right to a certain group of people in a particular context. ${ }^{94}$ To say that the TWU Covenant is contrary to the ethos of the legal profession because equality is a "fundamental value" of the legal profession elides the distinction between the two senses of equality and evades the arguments and judgments on which such an assertion rests. ${ }^{95}$ The abstract, or aspirational, idea of equality provides a starting point, not an answer, for addressing the question of whether to accredit TWU's proposed law school.

Regardless of how one might balance the values of equality and religion in relation to the ethos of the legal profession, the point I want to emphasize is that to ground the ethos of the legal profession in an abstract set of "fundamental values" profoundly shapes the way that the community of the legal profession is conceptualized. Whereas "virtues" focus on the lives of those who compose the profession, "values" focus on the nature of the profession itself, separately and apart from the lives and actions of its professionals. The legal profession, then, is divided between an abstract sense of "the profession" and its particular lived experiences.

This can be seen in the way that values are understood to become "fundamental" to the ethos of the legal profession. The Ontario courts describe the Law Society of Upper Canada (LSUC) as historically engaged in promoting equality. ${ }^{96}$ Equality is also located within the empowering statute of the LSUC, as part of the general obligation to protect people's rights. ${ }^{97}$ But what is missing from this restatement of the history of the law society and recitation of its legislative duties is how equality came to be the "characteristic spirit" of the legal profession, its "culture ... its attitudes and aspirations; [its] prevailing character." 98 The value of equality is simply presented as always there, as the essence of the legal profession that

Loyola High School v Quebec (Attorney General), 2015 SCC 12, [2015] 1 SCR 613 ("“[t]hese shared values - equality, human rights and democracy - are values the state always has a legitimate interest in promoting and protecting" at para 47). This passage was quoted in TWU ONSC, supra note 6 at para 119.

93 Tom Bingham, The Rule of Law (London, UK: Penguin Books, 2010), ch 5.

94 There is quite a bit of controversy over the meaning of "equality" and its use in law. Much of the recent discussion has focused on whether equality as a category is superfluous and confusing in law. See Peter Westen, "The Empty Idea of Equality" (1982) 95:3 Harv L Rev 537; Peter Westen, Speaking of Equality: An Analysis of the Rhetorical Force of 'Equality' in Moral and Legal Discourse (Princeton: Princeton University Press, 1990); Kent Greenawalt, "How Empty is the Idea of Equality?" (1983) 83:5 Colum L Rev 1167; Jonnette Watson Hamilton \& Daniel Shea, "The Value of Equality in the Supreme Court of Canada: End, Means or Something Else?" (2010) 29:1 Windsor Rev Legal Soc Issues 125; Rex Ahdar, "The Empty Idea of Equality Meets the Unbearable Fullness of Religion" (2016) 4:2 J L Religion $\&$ State 146. It is important to note that there are multiple ways to conceptualize the idea of equality in law: see e.g. Ron Levy, "Expressive Harms and the Strands of Charter Equality: Drawing Out Parallel Coherent Approaches to Discrimination” (2002) 40:2 Alta L Rev 393. My point here is simply to distinguish between the abstract idea of equality as an aspirational social ideal and the idea of equality as a right to be claimed in certain circumstances.

See Ahdar, supra note 94.

TWU ONSC, supra note 6 at paras 21-25, 95-96.

Ibid at paras 94, 97, 100; TWU ONCA, supra note 6 at paras 108-11.

OED, "ethos," supra note 72 . 
always was. In this sense, it is rather like a creed that can be accepted or rejected but not negotiated. Individuals (or institutions, like TWU) either conform to the ethos and become professionals or, if they cannot conform, remain outside of the professional community. There is no sense that the ethos of the legal profession emerges through or is shaped by the participation, deliberation, and action of its individual members.

In light of the discussion in the first half of this article, the portrayal of the "ethos" of the legal profession as an abstract set of fundamental values is deficient. Communal identity (its "ethos") is formed and evolves through a complex process of social interactions, between different communities and through the active engagement of individuals. Appealing to virtues to define the ethos of the legal profession captures much more of this process than an appeal to values. Professional life, from the virtue perspective, is not characterized by passively conforming to an abstractly defined norm. Instead, the guiding principles of a community emerge out of the lived experiences of individuals within the community, in the common pursuit of some common good or purpose. ${ }^{99}$ As Roderick Macdonald and Thomas McMorrow observe,

\footnotetext{
virtues are relational practices: dimensions of "who-we-are-in-being-with-others." It is orientation to the public good, not just each individual's private benefit, that characterizes the aspiration to lead virtuous lives. Each community member has the potential to find meaning in his or her participation to the extent one believes one can make a mark on the life of the institution and be shaped by the experience for the better. ${ }^{100}$
}

The ethos of the legal profession, from this perspective, is dynamically related to the lives of legal professionals and law students rather than statically related to fundamental values inherent to the profession.

\section{B. The Discipline OF LAW SCHOOL: ThE Divided SELF}

The "fundamental values" of the ethos of the legal profession do not operate entirely separate from the lives of individuals in the legal community. They are reproduced through social interaction, like any other aspect of communal life. This is particularly evident in law school. As J.M. Balkin observes, "[d]isciplines reproduce themselves through education; they construct the cultural software of new members in order to perpetuate themselves."101 Since the first step in coming to law in Canada is through a university education in law, the initial site of disciplinary formation of the legal profession is in law school. Legal education is where the community of the legal profession reproduces itself, shaping individuals into a form that comports with the values and ideals of the community.

The notion of "discipline" described here is distinct from what we mean when talking about a university discipline, although there is some overlap between these concepts. ${ }^{102}$ By "discipline" I refer broadly to the cluster of practices (both formal and informal) that shape

See e.g. Alasdair MacIntyre, Whose Justice? Which Rationality? (Notre Dame: University of Notre Dame Press, 1988), ch 3; MacIntyre, After Virtue, supra note 87, ch 15. Macdonald \& McMorrow, supra note 86 at 730-31 [footnotes omitted]. JM Balkin, "Interdisciplinarity as Colonization" (1996) 53:3 Wash \& Lee L Rev 949 at 956. See e.g. Helge Dedek, "Stating Boundaries: The Law, Disciplined" in Helge Dedek \& Shauna Van Praagh, eds, Stateless Law: Evolving Boundaries of a Discipline (Farnham, UK: Ashgate, 2015) 9. 
individuals in the journey of coming to the legal profession. In this sense, the discipline of legal education is not an object, but a process. The process of discipline affects a vastly complex and multifaceted set of habits of thought, self-perceptions, and relationships. Disciplines transform individuals by engaging with multiple layers of human experience. ${ }^{103}$

Legal education accomplishes more than the disclosure of the values and ideals that students and professionals of the legal profession are to follow; it shapes people, and imparts to them a set of habits that reflect the purposes and ends to which the community is oriented. The abstract notion of values and ideals, which ground the community of the legal profession, must be connected to the disciplinary practice of law school. As we will see, there is a deep resonance between the value-based conception of the ethos of the legal profession identified earlier and the discipline of legal education, which is also mirrored in the position taken by the CCLD regarding the accreditation of TWU's proposed law school. This disciplinary practice connects students (and professionals) to the community of the legal profession as its passive dependents.

Philip Kissam describes legal education as resting upon a "subterranean" and pervasive system of highly structured practices, including routines, habits, and a tacit knowledge, that make law school itself a form of discipline. ${ }^{104}$ These disciplinary practices form certain intellectual attitudes within its students, which are considered to be the marks of a true professional. ${ }^{105}$ Included here are dispositions toward precision, skepticism, confidence, toughness, and conservatism. The emerging image of the ideal lawyer is "as a quick, productive, error-free ... combative ... warrior" who avoids "open-ended, risk-taking deliberations about ethical, moral and political issues." ${ }^{, 106}$

But there is another side to the lawyer produced by the discipline of law school, which reflects the broader modern social phenomenon of the "divided self."107 According to Kissam, law school converges within the individual both the strong enlightenment notions of rationality, individuality, and universality as well as the romantic ideals of emotion, language, aesthetics, history, and relationships. The convergence of these conflicting ideals is achieved by partitioning the self into professional (public, rational, individual, autonomous) and personal (private, emotional, aesthetic, relational) spheres of life. ${ }^{108}$ The line that divides the professional and private is sufficiently vague to bend and move in such a way as to support the ideals of the legal professional mentioned earlier. A similar bifurcation is reflected in the modern legal context as a common conception of law as a

In this way, disciplinary formation might be similar to the process of religious conversion, which involves a complex "crystalline" structure of the entire human self. See e.g. Matthew Scherer, Beyond Church and State: Democracy, Secularism, and Conversion (Cambridge: Cambridge University Press, 2013), which explores the connection between religious conversion and the secularization of the state. Philip C Kissam, The Discipline of Law Schools: The Making of Modern Lawyers (Durham, NC: Carolina Academic Press, 2003) at 4. The practices that Kissam is particularly interested in examining are the tacit norms emerging from "the unintended actions and unintended effects of [these] actions" of law school (ibid at 11-12 [emphasis in original]). Macdonald \& McMorrow, supra note 86, offer a similar critique of law school as Kissam, except that they focus on the way in which law school is dominated by the influence of external "colonizing forces" (ibid at 719) rather than on the tacit forces internal to law school.

For an overview of these arguments, see Kissam, ibid at 6-11.

Ibid at 230 .

Kissam takes the idea of the "divided self" from Charles Taylor, Sources of the Self: The Making of the Modern Identity (Cambridge, Mass: Harvard University Press, 1989). See Kissam, ibid at 231-36.

Kissam, ibid at 235 . 
matter of technical definitions and distinctions, ${ }^{109}$ in the fracturing of legal knowledge from other forms of knowledge, ${ }^{110}$ and in the disposition toward coherence within the law. ${ }^{111}$ The modern conception of law and the disciplinary norms of legal education help make law students (and legal professionals) vulnerable to being co-opted by the ideals of the legal profession and formed into divided selves. ${ }^{112}$

The formation of the "divided self" in the discipline of law school is, according to Kissam, also accomplished through a profound sense of ambiguity about the meaning of the law taught in law school. On the one hand, the law is presented as systematic and rational, but on the other it is presented as fragmented and decontextualized. Through the methods of reading, teaching, and evaluation used in law school, students are constantly exposed to tensions and inconsistencies between legal authorities. ${ }^{113}$ The result is the appearance that "there is no law there" to bind judges, lawyers, or anyone else. ${ }^{114}$ There is no right answer, and everything can be argued from various perspectives. The "ideal lawyer" emerges as the master of ambiguity, able to represent multiple perspectives with conviction, unbound by the restrictions of one particular view.

The ambiguity of the law strengthens the socialization of individuals into the legal profession and their fidelity to the law. As students are exposed simultaneously to experiences of powerlessness and empowerment - overwhelmed with the plethora and fragmentation of material, and then instructed in appropriating the tools needed to master the ability to make compelling arguments out of this material - they become "engulfed" by the law, and come to accept the authority and values of the legal profession. ${ }^{115}$ The profession mediates our dealings with the law, making accessible that which on our own is unmanageable. The relational bonds formed through the process of legal education create a sense of belonging to this legal community, which is collectively working to confront uncertainty and to make sense of the law, and reinforce the sense of dependence on the community of the legal profession. ${ }^{116}$ This communal experience is important to the full indoctrination of the discipline. Ambiguity and the divided self enable the transformation of students into full disciples, indoctrinated — as future jurists — with this sense of ambiguity and dependence on the legal professional community. ${ }^{117}$

See e.g. Roderick A Macdonald, "Metaphors of Multiplicity: Civil Society, Regimes and Legal Pluralism" (1998) 15:1 Ariz J Intl \& Comp L 69; Martha Minow, Making All the Difference: Inclusion, Exclusion, and American Law (Ithaca: Cornell University Press, 1990).

See e.g. Gerald J Postema, "Law’s Autonomy and Public Practical Reason" in Robert P George, ed, The Autonomy of Law: Essays on Legal Positivism (Oxford, UK: Clarendon Press, 1996) 79.

See e.g. Desmond Manderson, "Beyond the Provincial: Space, Aesthetics, and Modernist Legal Theory" (1996) 20:4 Melbourne UL Rev 1048.

See e.g. JM Balkin, "Understanding Legal Understanding: The Legal Subject and the Problem of Legal Coherence" (1993) 103:1 Yale LJ 105. See also Pierre Bourdieu, "The Force of Law: Toward a Sociology of the Juridical Field" (1987) 38:5 Hastings LJ 805 (especially the introductory notes of the translator, Richard Terdiman). For a similar argument that uses an alternative metaphor of "boundary" for structuring the conception of the "self," see Nedelsky, supra note 2, especially ch 2.

Kissam, supra note 104 at 241. For Kissam's arguments on the way this appears in the various practices of law school, see ibid at 27 (the core curriculum), 34-35, 39-41 (casebook readings), 54-57 (examination).

Ibid at 118 .

Ibid at 241-42.

Ibid at 121 .

In his well-known essay, "The Ordinary Religion of the Law School Classroom” (1978) 29:3 J Leg Educ 247, Roger C Cramton describes a set of law school practices that result in similar attitudes. He focuses on the instrumentalist views of the ideal lawyer prevalent in law school, which engender a deep indifference toward the values of legal education and the legal profession (ibid at 250, 257-58). 
Some of these elements of the discipline of legal education can be seen in a letter written by the CCLD to the Federation of Law Societies of Canada (FLSC) committee reviewing TWU's law school proposal. ${ }^{118}$ In this letter the CCLD said,

Discrimination on the basis of sexual orientation is unlawful in Canada and fundamentally at odds with the core values of all Canadian law schools.

We would urge the Federation to investigate whether TWU's covenant is inconsistent with federal or provincial law. We would also urge the Federation to consider this covenant and its intentionally discriminatory impact on gay, lesbian and bi-sexual students when evaluating TWU's application to establish an approved common law program. ${ }^{119}$

On its face, this statement is straightforward enough. The CCLD is concerned about the rights of LGBTQ people in relation to TWU's Covenant. But the first and last sentences of this quotation read together - that discrimination is unlawful and that TWU's Covenant is intentionally discriminatory - imply that the TWU Covenant is in fact "unlawful." However, it is not simple or straightforward to say that the TWU Covenant is unlawful. It is true that in some contexts discrimination on the basis of sexual orientation is legally prohibited, but not in every context. Most notably, as was discussed earlier, the 2001 TWU $v$ BCCT decision upheld TWU's ability to maintain its Covenant in the face of section 15 of the Charter and human rights legislation in British Columbia. ${ }^{120}$ Although it is possible to argue that the TWU $v$. BCCT decision should not apply to the question of accrediting TWU's proposed law school ${ }^{121}$ (which is to say that in the context of legal education, discrimination by TWU on the basis of sexual orientation should be unlawful), such an argument provides shaky grounds at best for making the bold claim that the TWU Covenant is unlawful.

The reference to unlawfulness in the CCLD letter makes more sense if seen in relation to the claim that the TWU Covenant is "fundamentally at odds with the core values of all Canadian law schools." 122 From this view, to say that TWU's Covenant is unlawful is to assert that the essence of the Covenant is inconsistent with the essence of legal education. Lawfulness in this sense refers to something other than established legal principles (as set out in, for instance, in TWU v. BCCT), pointing instead to the values and ideals that form the basis of legal education. What is at stake for the CCLD can then be seen in relation to the formation of jurists that align with particular values rather than to the content of legal rules. This, as we have seen, is directly connected to the tacit knowledge imparted through the discipline of law school, in the skills, abilities, and habits of mind learned in law school.

The difficulty is the way that the CCLD Letter holds side by side the notions of unlawfulness in Canadian law and the "core values" of law school, treating them as though they are one and the same. The effect is to inject uncertainty into the state of the law, which affirms the disciplinary structure of law school described by Kissam. It also emphasizes the 2012), online: <www.ccld-cdfdc.ca/images/reports/CCLDnov20-2012lettertoFederation-reTWU.pdf> [CCLD Letter]. 
stabilizing role of legal education in defining and maintaining the institutional integrity of the law. Where the law is ambiguous, the law schools are not. By posturing the TWU Covenant (and the TWU v. BCCT decision) against the "core values of all Canadian law schools," the CCLD draws out the incongruity between the apparent state of the law and the "values" of legality and legal education. The invitation for the FLSC to consider the legality of the TWU Covenant is an invitation for the law societies to share a common "ethos" with law schools - to buttress against the swells and turbulence of the uncontrollable law and to guard the true essence of legality. ${ }^{123}$ Echoing Kissam's concerns, how are students supposed to view this assertion of institutional values other than as a call to submit themselves to the protective and enlightened community of the legal profession? Likewise, and perhaps more to the point, how is the TWU proposed law school to be perceived as anything other than an assault on the legal profession and, mutatis mutandis, on the law itself?

\section{The Challenge of TWU}

TWU's insistence on maintaining its Covenant disrupts the discipline of law school. For TWU the law is, at least in this case, not ambiguous - given its success in the TWU $v$. BCCT case, TWU holds onto its (religious) right to keep its Covenant. Implicitly, in claiming for its proposed law school the rights and privileges afforded to religious institutions, TWU is asserting that participation in the legal community should not require the passive acceptance of either the legal values or the professional identity encased within the discipline of law schools. Rather, TWU insists that its identity and values, as well as the identities and values of its students, remain grounded in the truths of divine revelation in the Christian scriptures (embodied for them in the Covenant). ${ }^{124}$

This orientation of TWU's proposed law school toward religious tradition opens up the professional and public aspects of law to forces ordinarily aligned with private religious life. TWU's mission, as a religious institution, is to prepare its students spiritually and professionally, equipping them to be fully-formed Christians who take on a profession with a public focus. ${ }^{125}$ In seeking to extend its mission through legal education, TWU challenges the boundary that divides private religious and public professional life.

This challenge has an existential ring to it if the ethos of the legal profession is defined in terms of fundamental values. From this view, the threat of an unambiguously evangelical Christian law school is the replacement of secular (or non-confessional) legal values with religious values and teachings. Not only does this threaten to change the positive rights protected by the law — such as legal protections for LGBTQ people — but it also erodes the

Milner S Ball, Lying Down Together: Law, Metaphor, and Theology (Madison: University of Wisconsin Press, 1985). To set these legal institutions up against the larger edifice of the law, especially the operation of legislative exceptions provided for TWU, resonates with a similar trend identified by Frederick DeCoste in the self-conceptualized role of the courts in relation to the other governmental powers. DeCoste disdainfully calls this the appearance of a new aristocracy. See Frederick C DeCoste, "The Separation of State Powers in Liberal Polity: Vriend v Alberta" (1999) 44:1 McGill LJ 231, especially at $242-48$.

See TWU, "Covenant," supra note 5. See also Trinity Western University, "Core Values," online: $<$ www.twu.ca/about/core-values> [TWU, "Core Values"].

125 See TWU, "Core Values," ibid. It should be noted that the straddling of the public and private divide was also pertinent to the decision in TWU $v$ BCCT, supra note 12, where the propriety of training future public school teachers at TWU was under question. 
foundations on which the law is thought to rest. Elevating religious values and religious life, as TWU does, opens the question of whether the authority vested in the legal professional community could just as well be replaced by religious authority. As was explored earlier, this escalation from questioning particular values to undermining the entire legal system is a result of the way that values are tied to the legal professional community - the values are the community, constituting the very ethos of the community. If these values are threatened then so is the community.

But this view of TWU's argument is not complete. TWU does not, in fact, propose to supplant secular legal values with religious values or the legal professional community with religious community. This can be seen in the way that TWU distinguishes between the actions of the institution and the actions of individuals within the institution. Although TWU claims for its proposed law school the ability to exclude people based on sexual orientation, it maintains that its law graduates are not being taught to act, and in all likelihood will not act, in a discriminatory way toward sexual minorities in the course of professional practice. ${ }^{126}$ Likewise, TWU emphasizes that despite the clear position in the TWU Covenant on human sexuality it is not permissible for students to engage in homophobic behaviour. ${ }^{127}$ TWU's proposal allows the institution to be openly exclusionary toward LGBTQ people in a way that individuals cannot be.

This feature of TWU's proposal is not entirely surprising given that the law of religious freedom in Canada maintains a stark distinction between private "beliefs" and publicly "acting" on those beliefs. ${ }^{128}$ TWU's proposal does not deny the separation between religion and law. In fact, it reinforces the division between collective (private) identity in the faith and individual (public) identity as a legal professional. Arguing for strong religious freedom for TWU as an organization on the basis that it is private and religious seems to push religious identity further into the private realm and professional identity further into the public realm. This sends the message that the ideas embodied in the TWU Covenant will be contained within the institution of TWU and within the interior thoughts of TWU graduates, which reinforces the view that religion (organizationally and personally) can only appear in the public space if it does not make any difference to the public space. ${ }^{129}$ Rather than disrupting the integrity of the legal profession, TWU's proposed law school seems to be, for the most part, maintaining it.

The trouble is making sense of how this somewhat innocuous view of TWU's proposed law school relates to the rather radical aspect of TWU's mission to unify religious and professional life, as noted earlier. From the view provided by the competition between fundamental values, it looks like there is a fairly significant inconsistency between the two. But things appear differently if we look behind the TWU "values" regarding the unity of religious and professional life to the religious theological tradition that informs those values. Even a cursory view of the Christian tradition would reveal that the distinction between the

\footnotetext{
126 Letter from Trinity Western University to Federation of Law Societies of Canada (17 May 2013) at 5 in FLSC, Final Report, supra note 28, Appendix B.

See TWU Written Argument, supra note 20 at para 22.

Most clearly stated in TWU $v$ BCCT, supra note 12 at para 36.

This is precisely what the law societies and the legal community are arguing for. See Victor M MuñizFraticelli, "The (Im)Possibility of Christian Education" (2016) 75 SCLR (2d) 209.
} 
public and the private that marks legal professional and religious identities also has roots in an ongoing theological discourse that distinguishes between sacred and profane. ${ }^{130}$ Somewhat surprising, perhaps, is the realization that the preservation of secular legal values distinct from sacred religious truths is not only the concern of the legal profession, but also of the Christian tradition.

The point is that "values" cannot be isolated, but must be understood in relation to the social and communal context within which they appear. The conflict over the TWU proposed law school can be critically engaged more fully if we are able to draw on a much larger range of social and communal considerations than what is available through imagining communal ethos in terms of fundamental values. The distinctions that appear between public and private, professional and individual, or institutional and individual are tensions that exist within (and are produced by) the processes of historical, political, philosophical, and social discourse. ${ }^{131}$ Treating these distinctions as rigid "values" that are either accepted or rejected separates them from their social and communal contexts. This makes it difficult to articulate why certain values are central to a particular community - failing to account for the processes by which values are formed inhibits our ability to discuss them intelligibly. It also makes it difficult to see the connections and overlaps between different values and ideals.

TWU's proposed law school does much more than assert a confessional aspect of professional life. The open acknowledgment in the TWU Covenant of the disciplinary aspect of the TWU community takes an important step toward bridging the gap between the meaning of values and the social processes by which they are formed. By placing the disciplinary aspect of professional education first, the TWU Covenant thrusts the structure of community, of its own community as well as the community of the legal profession, into dialogue. In other words, the TWU Covenant challenges us to take account of the social processes by which communities define themselves, through their boundaries, ethos, and discipline.

In doing this, TWU challenges the way that the relationship between the individual and community is understood. Students in law school, as Kissam shows, are passively shaped by tacit knowledge, practices, and habits, which foster the separation between individual and professional identity. The individual has to receive or accept the values and ethos of the community separately from their participation in the community. Closing, or hiding, the discipline of law school in this way separates the meaning of legal values, the thing to which the legal profession is committed to, from the social process, or discourse, by which the values are authorized as authoritative. ${ }^{132}$ To the contrary, TWU students are invited to actively accept the discipline offered through the Covenant. TWU's community and established law schools are equally disciplinary, both calling for conformity to their communal structure. The difference between them is that at TWU, community values and Merrill Umphrey, eds, Law and the Sacred (Stanford: Stanford University Press, 2007) 29; Robert A Yelle, "Moses' Veil: Secularization as Christian Myth" in Winnifred Fallers Sullivan, Robert A Yelle \& Mateo Taussig-Rubbo, eds, After Secular Law (Stanford: Stanford University Press, 2011) 23; Scherer, supra note 103. 
disciplinary practices are connected to each other, which grounds the discussion of these values and practices in the social and communal processes in which they are formed and evolve. TWU's proposed law school pushes away from the centralized and tacit knowledge of the legal profession and toward the active engagement of legal professionals (and law students) with the foundational discourse of the legal professional community. Not only does this foster individual responsibility for the community of the legal profession, it also opens the possibility of connecting the profession to other communities and to the role of other communities in the evolution of the values and practices of the legal professional community.

The current dispute between TWU and the law societies has to be seen as part of the process of the social interactions that give shape to the community of the legal profession. This means that in the dialogue with TWU over the accreditation of TWU's proposed law school, the law societies and the legal profession cannot claim a status that is external to, or standing above, the social nature of the dispute. The argument cannot be solely about the "fundamental values" of the ethos of the legal profession, as if the integrity of the profession and its values are things that must be protected and preserved in an abstract sense. Rather, the integrity and values of the profession must be seen through the context of the social processes that have shaped the profession and that currently shape the profession.

In the end, I do not think that this challenge posed by TWU's proposed law school is necessarily a threat to the legal profession. It does not try to supplant the community of the legal profession or displace the tradition of the rule of law in Canada. It does, however, issue a strong challenge to the way we think about the legal profession and legal education, which does not allow the separation of values from the social processes that shape the community over time. The mere fact that TWU's proposed law school disrupts the abstract fundamental values of the legal profession is not a sufficient reason to refuse to accredit TWU. Instead, the practices and values of the proposed TWU law school, and the way that it engages and shapes the lives of its students, will have to be evaluated in relation to the purposes and goals of the legal profession. Alongside this, the legal profession will also have to hold the mirror up to its own practices to ensure that those practices continue to express the purposes and goals of the profession.

Of course, this still leaves open questions about whether the standard of sexual conduct at TWU can be permitted in the context of legal education. However, the way in which this question is asked and answered will be radically changed. In terms of values, TWU proposes simply a slight adjustment to the boundaries presumed to exist between law and religion, as embodied in the laws of religious freedom. It is possible, though, to see TWU's proposed law school as a challenge towards deeper understanding of community, which affects the way that the boundary between law and religion is understood.

\section{CONCLUSION: STRUCTURING THE CONFLICT IN TERMS OF COMMUNITY}

The two quotations used to start this article frame quite nicely what I take to be the central lesson of the conflict over the accreditation of TWU's proposed law school. The idea of a confessional law school in Canada is uncomfortable for many because it threatens a tacit sensibility about what it means to be part of the legal profession and to participate in the role 
that the institutions of law play in society. Perhaps the threatening feeling roused by TWU's insistence that it "plant its flag everywhere" ${ }^{133}$ does not foreshadow the collapse of liberal legal education or legal practice (as Stanley Fish might suggest). Rather, the desperation to keep the boundaries of the legal profession where they are shines a light on the profound responsibility to pursue openness and unity in the face of diversity (as Jennifer Nedelsky might say). The metaphor of a boundary helps us understand the nature of this threat and, I believe, helps dispel the foreboding that it engenders. The conflict and tension experienced in relation to TWU's proposed law school is the inescapable stuff of social reality: we can either hide from it in fear, or face it with courage and grace.

I have not said, nor will I say, whether I think TWU should be able to have its law school accredited. That must be left for another analysis and a different time. What I have demonstrated here is that to refuse accreditation on the basis of the threat to the legal profession is fraught with peril. It is disposed toward an uncritical view of the nature of the legal profession, which fails to recognize and account for the social and communal aspect of the dispute. With this in mind, regardless of what the result of a more thorough and critical evaluation of the TWU proposed law school might be, the tone and focus of the dialogue would surely be remarkably different than what has transpired so far.

Drawing together the two halves of this article, the disagreement over how to characterize the "ethos" of the legal profession in relation to the accreditation of TWU's proposed law school seems to operate like a symbolic boundary marker of the community of the legal profession. The "ethos" of equality and merit crystallizes in response to the encounter with the religious "other" (that is, the "threat" of TWU's proposed law school). The way in which this symbolic appearance of "ethos" is understood is very important. If it is understood too rigidly, and as persisting independently of the practices of community and the lives of individuals, then the ethos of the legal profession precludes any dialogue with TWU (and other religious communities). Nothing other than the logic flowing from the internal and autonomous "ethos" of the profession will be accounted for: legal principles will be used and everything else will be left out.

If, on the other hand, "ethos" is understood too openly and without consideration for the character of the community, then the aspirational quality of the law and the legal profession will be lost from view. Standing between these two drastic options is the idea of virtue, which ties together the life of the individual and the life of her community, as well as the values of the community and its disciplinary practices, making the experience of each interdependent with the other. This locates the "ethos" of community in relation to the process by which a community constitutes itself through the lives of its members, and through their integration together according to a common purpose and goal.

The dynamic interplay between individual and community is very helpful in framing the conflict over the accreditation of TWU's proposed law school because it provides a context within which both fundamental legal values and individual character formation can be located alongside each other. From such a perspective, the TWU Covenant can be put into conversation with the legal profession. The "values" of each perspective can be reframed in 
terms of the goods and purposes to which each community is oriented, which are constantly being refined by the lived experiences of TWU members and legal professionals alike. The religious ideas that motivate the institution of the TWU Covenant will not be disregarded out of hand, but will be engaged in the framing of the nature of the legal profession, the nature of the practice of law, and the form of life of the legal professional.

I believe that there are at least three effects flowing from this discussion of the way that we approach TWU's proposed law school. First, we should be wary of attempts to decipher an external principle to resolve the situation - appealing to the "true" natures of the communities or the proper application of the law. Second, we should do what we can to avoid the exclusion of these communities from each other. Looking to external solutions, or to disarming the conflict between TWU and the law societies, denies the social process that is at the heart of social life. Trying to remove some aspect of the conflict from the social process would have significant implications. Appealing to an objective principle divests the communities of their responsibility to work together and produce a solution. Separating the solution from the lived experience of the conflict freezes the discourse on which the conflict is based. To construct an external solution or synthesis to resolve the conflict denies the social process that is at the heart of the interaction, and only succeeds in deferring questions about the foundations of community that are central to resolving the matter of accreditation.

Third, my contention is that at some point it is necessary to allow social interaction to carry out its work and to produce its own solutions. This requires the cultivation of trust because trust allows the push and pull between different perspectives, ideals, and communities to generate a solution. ${ }^{134}$ Ultimately, when we invest the communities and individuals involved with the responsibility to work together to produce a solution, this is the solution that will be the most sustaining. 